Article

\title{
From Single-Use Community Facilities Support to Integrated Sustainable Development: The Aims of Inter-Municipal Cooperation in Poland, 1990-2018
}

\author{
Marek Furmankiewicz ${ }^{1, *(1)}$ and Adrian Campbel1 ${ }^{2}$ (D) \\ 1 Department of Spatial Economy, The Faculty of Environmental Engineering and Geodesy, \\ Wroclaw University of Environmental and Life Sciences, Grunwaldzka 55, 50-357 Wrocław, Poland \\ 2 International Development Department, School of Government and Society, University of Birmingham, \\ Birmingham 15 2TT, UK; a.campbell@bham.ac.uk \\ * Correspondence: marek.furmankiewicz@upwr.edu.pl
}

Received: 4 October 2019; Accepted: 21 October 2019; Published: 23 October 2019

\begin{abstract}
The paper explores and compares the aims of the three most common legal forms of inter-municipal cooperation in Poland (engaging rural, urban-rural and urban municipalities) during the years 1990-2018: Mono-sectoral Special Purpose Unions, Municipal Associations and cross-sectoral Local Action Groups. Content analysis was applied and development priorities from the statutes and strategies were studied. The main form of territorial association evolved from, initially, mono-functional bodies concerned mainly with local infrastructural investment and managed solely by a group of local authorities, to a devolved type, consisting of multi-purpose associations managed with the participation of economic and third sector representatives. This was the result of the European Union policy of promoting territorial governance and integrated development in functional regions, this being considered as part of the process of Europeanisation. However, these successive forms of municipal cooperation do not appear to have replaced the pre-existing forms, but they have introduced additional modes of governance of local resources. The findings show that the most "integrated" and "sustainable" management of local resources is observed mainly in cross-sectoral partnerships, like Local Action Groups, but not so often in mono-sectoral municipal unions and associations led solely by local government and focused more on hard infrastructure and municipal facilities. However, given the specialisation shown by each of the three types of association, it is likely that the full range of development possibilities in the areas concerned can only be realised if all three forms of cooperation are present. The analysis confirms the positive role of local economic and social sector participation in shaping sustainable development. The findings also indicate the utility of the concept of cross-sectoral territorial partnerships in post-socialist and post-authoritarian countries lacking traditions of grassroots or participative development.
\end{abstract}

Keywords: inter-municipal cooperation; cross-sectoral partnerships; place-based and integrated development; sustainable management; integrated planning index; Poland

\section{Introduction}

In recent decades, best practice in public policy and administration has been declared to be undergoing a gravitational shift from top-down state intervention to bottom-up participation and co-management with collaboration across agency, state and non-government organisation (third sector) boundaries, a trend associated with the growing popularity of the territorial governance concept [1-3]. It has been seen to support decentralisation (empowering local government) and devolution (empowering non-governmental stakeholders in public sector decision making). This may 
be seen as facilitating a "neo-endogenous" or "integrated place based" model of development, in contrast to a top-down, exogenous and sectoral model focusing on single issues such as transport or agriculture and managed solely by government [4-6]. The place-based, neo-endogenous model implies central government support for regional and local bottom-up initiatives for development and well-being, facing one particular territory (natural or economic region, agglomeration, etc.), often requiring cooperation between stakeholders from fragmented administrative areas [7-9]. Integrated planning in this context is understood to involve drawing together local social, economic and ecological issues, rather than focusing only on, for instance, technical infrastructure [10]. It is often closely related to "sustainable" development, which involves an additional concern with long-term retention of local natural resources [11-13]. In the countries where these processes first emerged, they were rooted in pre-existing democratic traditions, whereas in the European post-socialist countries such principles have largely developed since the beginning of the 21st century where they were disseminated, mainly with the support of European Union (EU) policy and funding as a means of achieving social, economic and environmental regeneration [14-16].

Cooperation between democratically elected local governments in the management of local resources, know-how exchange and common interest representation has a long tradition in Europe and takes many domestic and cross-border forms (see, for example, [17-19]). These range from simple networks and contractual agreements to dedicated structures, which may be legal entities in their own right, for politically-sensitive or capital-intensive tasks [20-22]. However, from the 1980s onwards, a new, broader model of territorial governance and development based on cross-sectoral partnership between representatives of local governments, non-governmental organisations, private firms and state institutions began to take the place of traditional mono-sectoral or hierarchical approaches, the latter being increasingly seen as remote from local concerns, as well as being weak on sustainability [23].

Integrated and sustainable development are frequently cited as aims of EU programs and projects related to territorial cooperation in functional areas, not least in Poland $[7,24]$. However, the question arises as to how far these fashionable slogans, proclaimed to facilitate access to European Union funds, are actually reflected in the objectives and tasks of the territorial organisations created by these funds, with the participation of local authorities. Is the shift from focusing on communal infrastructure to more sustainable and integrated management of local resources, taking into consideration environmental, business, cultural and social issues, perceptible in the priorities espoused by collaborative municipal organisations? To answer this question we will assess the evolution of municipal cooperation objectives, based on the Polish case and its three most common forms of territorial cooperation: Special Purpose (municipal) Unions, Municipal Associations and "special" (cross-sectoral) association (Local Action Groups) and their respective aims, as listed in their statutes or strategies. We seek to evaluate how the change of policy context was taken into account in the reforms and policy changes implemented. Local government cooperation and cross-sectoral partnerships are often considered and discussed separately in the literature $[18,25,26]$. However, they are both forms of municipal cooperation, only differing in the degree of local community participation in decision-making. In this paper we compare both kinds of territorial inter-municipal cooperation, thereby filling what appears to be a gap in the current literature.

The following section gives a brief overview of the emergence of the place-based, integrated and sustainable development concept, which is strongly connected to the concepts of neo-endogenous development and territorial (collaborative) governance. Next, the legislative, institutional and economic basis of municipal cooperation in Poland in the years 1990-2018 is analysed in terms of the main aims of municipal unions and associations. We found that the evolution from mono-functional authority-led to multi-purpose partnership-based co-operation did not occur gradually but was directly initiated by administrative reforms or by EU policy and, moreover, that the three forms of cooperation typically differ in their development priorities. 


\section{Conceptual Background}

Regarding economic development strategies, two basic models have been identified: exo- and endogenous development [27]. The first emphasizes top-down management using external technology, capital and human resources, often organised in separate, sectoral agencies under central government control (e.g., agriculture, industry, culture). The second concept, the endogenous (or grass-roots) approach, encourages bottom-up development factors, trusting in the sustainable use of local resources for socio-economic development by cooperating residents [28,29].

The exogenous model of sectoral development policies was common in democratic countries in the mid-20th century and dominated in the socialist (or "communist") countries of Central and Eastern Europe to such an extent that independent local and regional self-government did not exist, in Poland for example, until these were re-introduced in 1990 [30-32]. However, in the Western liberal democracies, in the 1980s, that model of development policy began to be perceived as ineffective and even detrimental, leading to regional disparity, environmental damage and the degradation of nature [33-35]. As a result, a neo-endogenous approach, based on territorial cross-sectoral cooperation of local stakeholders (i.e., on territorial governance processes) began to gain favour $[4,36]$. The model of territorial governance as a horizontal, cross-sectoral regional network has tended to be most pronounced in the Anglo-Saxon countries and has remained popular through much of Western Europe where traditions of co-operative governance are strong, not least because the state is sufficiently powerful to be confident of maintaining the initiative in partnerships [26,37,38]. In developing countries the notion of collaborative governance has been widely promoted as a means of legitimising and strengthening the role of civil society in the management of public goods in the absence of sufficient local state capacity or for increasing state accountability $[39,40]$. Collaborative territorial governance may be seen as an instrument not only for the production of public goods and management of local, limited resources, but also for changing the nature and logic of state-society relations in a given country [41]. It was disseminated throughout most European post-socialist countries from the early 21st century, mainly after their accession to the European Union [42,43]. The term "endogenous development" is considered as more or less synonymous with the "grassroots", "bottom-up" or "participatory" approach to management of local resources and is closely related to "sustainable development" in policy practice [44,45].

The advantages attributed to local stakeholders' territorial cooperation encouraged EU policy makers to promote neo-endogenous and place-based integrated development, in which such governance processes have an important role, and have similar features and are considered more sustainable than the top-down exogenous approach $[23,46,47]$. These models seek to construct a hybrid of top-down and bottom-up development by incorporating top-down support for bottom-up territorial governance in functional areas [9]. According to Ray [4], neo-endogenous development has a strong emphasis on local resources, capacities, perspectives, needs and knowledge but it also involves hierarchical management of incentives and the replacement of the principle of "administrative territory" by a functional principle, with inter-sectoral co-operation through regional networks and partnerships and increased self-governing responsibilities at regional or local levels [48]. In other words, these models assume the mobilisation of local stakeholders, their knowledge, demands and concerns by instruments and territorial organisational forms determined by central government, for example, via financial grants with territorial partnership creation as conditionality. The approach is seen to further the European Union's objectives of smart, inclusive and sustainable growth [45].

The term "place-based development" was popularised initially by the Organisation for Economic Co-operation and Development (OECD) report [23] and the Barca report to the European Union [49] as a means of social inclusion and participatory and fair process in development policy. It implied territorially sensitive, multi-sectoral approaches, involving multilevel governance and co-ordination of all relevant levels, policies and stakeholders [50,51]. The approach informed the creation of area-based development partnerships in functional regions, managed by diverse local stakeholders, for instance EU Local Action Groups in rural and urban areas within the framework of Community-Led Local 
Development [52-54], Integrated Territorial Investment Partnerships in metropolitan areas [15,55], "Urban Action Europe" (URBACT) Local Support Groups in cities [56] and others. Place-based development, according to Zaucha and Światek [7], is a long-term development strategy aimed at reducing persistent inefficiency (underutilisation of the full potential) and inequality (the share of people below a given standard of well-being and/or extent of interpersonal disparities) in specific places. It can be attained through the production of bundles of integrated, place-tailored public goods and services, designed and implemented by eliciting and aggregating local preferences and knowledge through participatory political institutions, and by establishing linkages with other places. It can be promoted from outside by a system of multilevel governance in which grants, subject to conditionality on both objectives and institutions, are transferred from higher to lower levels of government [57]. Both place-based and neo-endogenous development emphasise the need to take into simultaneous consideration the social, economic and environmental needs of the locality, through a cooperative network of different local and external stakeholders, an approach which is termed as "sustainable" or "integrated" [45,55,58].

This strong emphasis on stimulating cooperation in functional regions, which often cross administrative boundaries, means that various forms of inter-communal networks become a common feature of place-based or neo-endogenous development initiatives. The main aims of local government are to fulfil local residents' needs and the sustainable well-being of their territory [59,60]. However, if local self-governments are focused on activities inside their territory, why should they cooperate? There are two main reasons; the need to deal with problems that go beyond the boundaries of the territorial unit and the opportunity to obtain additional benefits resulting from group work [61-63]. Collaboration can facilitate economies of scale, the attainment of "critical mass" in specialised activities, synergy, policy learning and better quality of municipal services [64-66]. Inter-municipal, territorial cooperation helps cope with problems that are not contained within the local administrative boundary [67,68]. According to Bennett [69], many administrative structures are "under-bounded": the functional activity space crosses over many small communal or local government boundaries (i.e., lakes, rivers, public transport areas). Local communities' cooperation is also very important in sustainable management of territorially limited resources [70]. As a result, local area-based cooperation is common, especially given that, in a purely territorial system, each community interacts much more with neighbouring units than with those who are far away [71]. In planning practice, a territory can be delimited by a grouping of dominant functions, not only by administrative division, creating a functional region [10,72]. The negative effects of local self-government fragmentation into a large number of small municipalities may encourage local authorities to pool the management of local resources, co-operation being the only practical alternative to amalgamation as a solution for this problem, especially if the many types of functional areas that overlap each other are taken into account [73].

In traditional democratic governmental systems, local authorities have carried out their responsibilities through their own sectoral cooperation, which is a common historical phenomenon given that they are typically part of the same functional local economy [71]. The empirical data shows that local authorities in many developing countries focus on infrastructural and economic issues [72,74]. However, the needs and ideas of local inhabitants may go beyond visible infrastructure investment. As a result, the newer concepts of development and governance support also cross-sectoral cooperation, gathering public as well as private stakeholders (both business and NGOs) to take into consideration their different needs. Area-based partnership in functional regions is seen to create better mutual understanding, added value, increased budgets and a reduction in duplication of provision [41,75].

In the context of EU policy, partnerships were expected to enable co-ordination of individual actions and information exchange leading to more sustainable and integrated development, not only economic growth $[24,45,76]$. The reality has not always conformed to this idealistic template. The wider literature testifies to the existence of partnership governance problems: Interest group conflicts, state domination, weak accountability, possible clientelism, exclusion of the weakest local stakeholders' 
needs-especially in post-socialist countries [77-79] and Mediterranean countries [80], but, to a lesser extent, also in the older western democracies [81]. However these constraints are not the main subject of this paper.

How far is the dissemination of sustainable and integrated development policies, based on territorial cooperation in functional regions supported by external programmes, actually reflected in the goals and priorities of inter-municipal organisations in, for example, Poland? Did the changing development preferences of inter-municipal cooperation over the last three decades lead to observable differences between their mono-sectoral and cross-sectoral forms?

The case of Poland, which started deep transformation in 1990 after more than 40 years of a top-down, centralist socialist system, may be instructive for countries that are preparing or implementing reforms after a period of centralist, populist or authoritarian rule, not only in Central and Eastern Europe, characterised by similar historical-cultural conditions, but also further afield, wherever top-down exogenous development policies have been applied. The results of our analysis may also be useful for policy makers and managers of development programs in the European Union. This is especially important because various programs and projects are already operating to disseminate methods of territorial partnership governance or place-based development at the local and sub-regional level in newer democracies, for example, in Georgia [82]. Our results are also an argument not to consider mono-sectoral cooperation of local governments and cross-sectoral territorial partnerships with the participation of a minimum of two municipalities as separate phenomena, which until now was the norm in the literature discussing forms of inter-municipal cooperation. It also supports the thesis that wide cooperation of local communities in the management of local resources (participative governance) leads to more sustainable development.

\section{Materials and Methods}

We analysed three of the most common forms of domestic municipal cooperation in Poland: Special Purpose Unions (SPUs), Municipal Associations (MAs) and Local Action Groups (LAGs), which have the legal status of special associations and are a kind of cross-sectoral partnership. In the paper, we use the name "municipality" for all three kinds of local government in Poland; rural commune, rural-urban and urban municipality (gmina: wiejska, miejsko-wiejska and miejska). In the research, we omitted the commercial partnerships and foundations created by municipalities to maintain selected community services, local tourist organisations (some created without local government) and individual agreements of municipalities (which are not registered at national level). According to Kołsut [83], they constitute less than $18 \%$ of the instances of local self-government cooperation, so we can focus on formal associations and unions. We also omitted associations for international cooperation (i.e., Euroregional associations, town-twinning) and focused only on in-country co-operation. We also did not consider Integrated Territorial Investment Partnerships in urban agglomerations, because they have various legal forms and organisation. We analysed only organisations with first-level local governments' involvement, so inter-county (powiat) and inter-regional (województwo, voivodeship) cooperation were not covered by our comparative study.

We used inductive methods of content analysis from "social artefacts" (manuscripts) used initially in social sciences $[84,85]$. We analysed whether a given subject was taken into consideration in priorities and formal tasks listed in the statutes or (if these existed and were available) the main strategies of the analysed organisations. The subjects were categorised in terms of eight main types:

- Common spatial or strategic planning,

- Common interest representation or promotion (both tourist and investment promotion, lobbying of higher public authorities),

- Social or human capital development (social inclusion, education and training, support for local voluntary organisations and cultural affairs),

- Enterprise (entrepreneurship) or employment development (local product development, local services development, enhancing employment), 
- Tourism or recreation (small tourist and sport infrastructure, support for agro-tourism),

- Social services or infrastructure (refurbishment of public buildings such as social welfare establishments, voluntary fire brigade buildings, pavements, playgrounds, neighbourhood schools and kindergartens, public transport services),

- Technical infrastructure or roads (water supply systems, gas and electricity networks, internet networks, car parks and roads),

- Environmental protection or ecological infrastructure (sewage systems, sewage treatment plants, thermo-modernization of public buildings, ecological waste management, nature conservation).

This methodology has a potential weakness in that the authors' subjectively assign freely formulated aims into strictly defined categories, and these might not show the real level of cooperation. However, it is considered acceptable to study development policy preferences from strategic or programming documents [86-88]. The LAGs concerned were each obliged to prepare a common strategy, so this was taken into consideration in Figures 4 and 5 in the results section, even when "common planning" was not listed among the aims. We consciously did not analyse the intensity of cooperation (which in SPUs can be much stronger and based on infrastructure construction and sustaining, than in MAs, focusing on small soft projects) but only the development preferences listed in the goals and tasks. We considered only LAGs with a minimum of two municipalities (communes) as members.

Research periods have been distinguished on the basis of the analysis of the year of establishment of organisations that existed in 2018 (Figure 1) and the year of new development policy implementation (reforms, joining the EU, EU programming periods, etc.). We have no comparable data about all liquidated (unregistered before 2018) units.

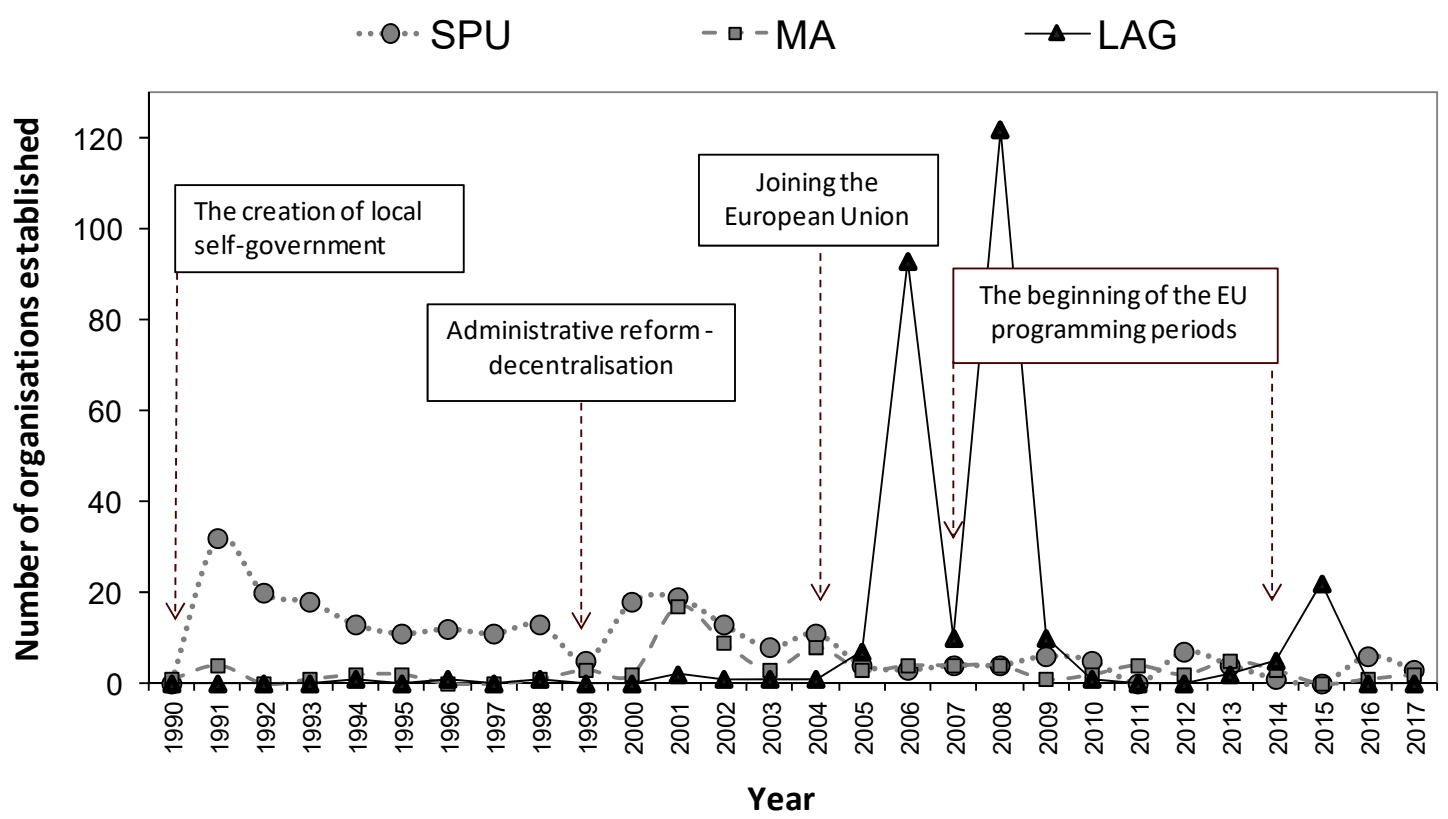

Figure 1. The number of analysed organisations established in a given year (only those existing in 2018 were analysed). SPU—Special Purpose Unions; MA-Municipal Associations; LAG—Local Action Groups. There is a visibly the growing number of establishments over some years (this is analysed in Section 4). Source: The Authors' own research.

Data was gathered from the registry of Special Purpose Unions run by the Polish Ministry of Internal Affairs and Administration, valid on 30.06 .2018 (downloaded in January 2019), the list of Municipal Associations from the National Court Register (Krajowy Rejestr Sadowy, own query October-December 2018) and from the territorial partnership strategies published obligatory by the Local Action Groups, valid on 31.12.2011 and 31.12.2018 (downloaded in 2012 and 2019). These 
registers of different forms of cooperation contain similar data on the year in which cooperation was established and the associations' main aims or tasks, listed in their statutes or strategies. The last year fully considered for all researched forms of cooperation is 2017; however, most of the data are valid also for 2018 (for instance, there were no changes in the development priorities of studied organisations).

Additionally, we devised a simple integrated planning index (IPI, Tables 1 and 2 in Section 4) showing the average percentage of organisations choosing a given subject (the index is lowest when all organisations list only one subject, and highest where all organisations take into consideration all subjects in goals or tasks). The high IPI is considered as a feature of integrated and sustainable development.

\section{Results}

Local self-government, based on the rural commune, rural-urban and urban municipality (called gmina) in Poland was established according to the Local Government Act of 8 March 1990 and by subsequent legislation. A crucial role in installing both democracy and local cooperation was played also by the Law on Associations. This enabled both individuals and legal entities, including territorial self-government, to organize formal associations to deal with issues that concerned them. This widespread type of collaborative organisation may be termed municipal associations (MAs, stowarzyszenie gmin). The first MAs were initially the country-wide ones such as The Union of Polish Metropolitan Towns (1990), The Association of Polish Cities (1991), The Association of Rural Gminas of the Republic of Poland (1993) and others. Territorial associations of municipalities typically appeared later. The law did not permit them to provide basic communal services, so they focused on representation of common interests and on human capital building (Figure 2), typically education and trainings for clerks. There were only a little over a dozen MAs created across Poland before 1998.

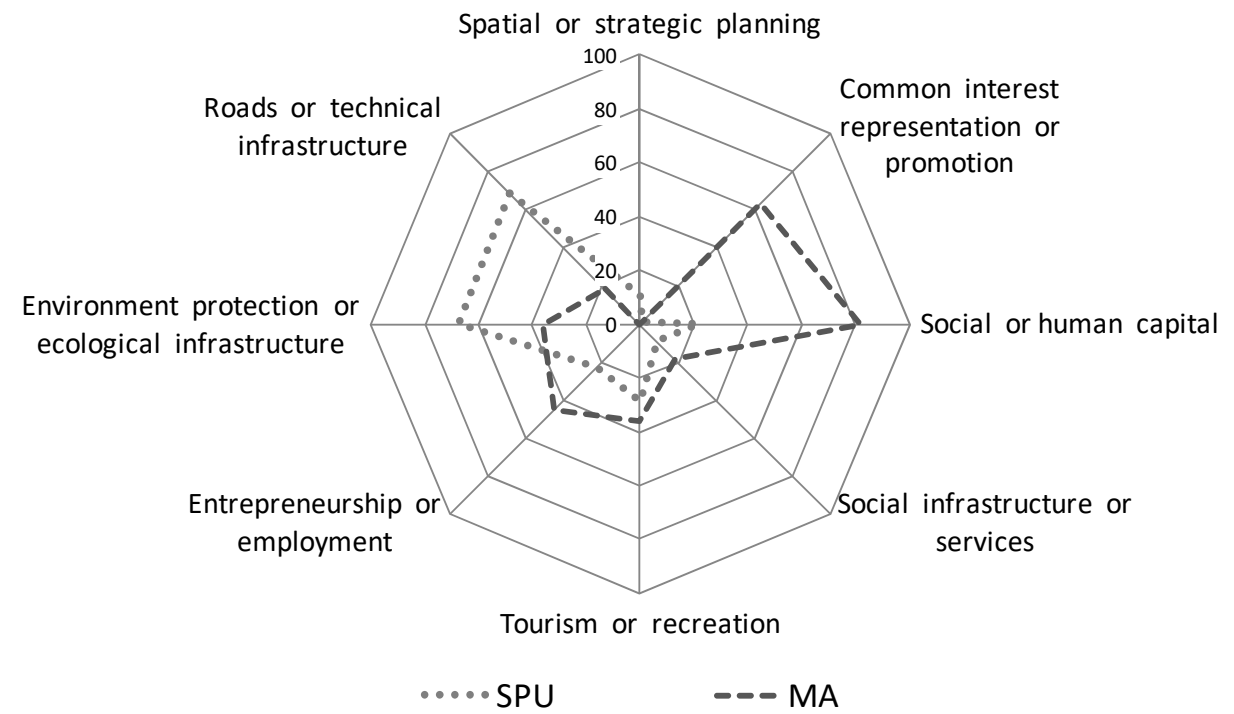

Figure 2. The percentage share of analysed organisations including a given subject in their priorities, by organisations created in the years 1990-1998: SPU-Special Purpose Unions; MA-Municipal Associations. The degree of specialisation in these forms of cooperation is evident. The Authors' own research.

Polish law also allowed individual municipalities to form Special Purpose Unions (celowy zwiazek międzygminny). The SPUs can provide communal services on participants' territory (e.g., sewage treatment, public transportation, water supply) and have been the most numerous bodies of local territorial collaboration from the outset. During the years 1990-1998, between 13 and 47 SPUs were established annually to deal with public utilities, focusing on investment in hard technical and ecological infrastructure (Figure 2) like gas, water and sewage supply, waste dumping sites and roads, and some of them were even deregistered after investment completion. There were almost no 
cross-sectoral territorial partnerships involving non-state partners at that time. The literature gives only one example of a rural bottom-up, area-based partnership in four municipalities in south-east Poland [89].

From 1990 to the end of 1998, the only form of self-government was the municipal (gmina) level. The 49 voivodeships (województwa) were central government regional administration. On 1 January 1999, however, a three-tier system of government administration was introduced. The upper levels of self-government, named powiat (county, district), and województwo (voivodeship, region) were created $[31,90]$. These soon began to engage in various forms of cooperation.

After the reform, at the local level, the SPUs remained the main form of municipal territorial cooperation (from 5 to 23 SPUs were established yearly, 1999-2003), but the role of Municipal Associations (MAs) increased. At the end of 2004, according to researched sources, there were 247 SPUs and about 46 multi-purpose MAs. According to our data, in 2001 about $90 \%$ of inter-municipal networks were of a local (micro-regional) character, working most commonly on functional areas lower than the region, most frequently with several municipality members.

Most SPUs existing at that time had been created during the first half of the 1990s, while the MAs were established most frequently in the years 2000-2003. The SPUs have usually remained mono-functional, focusing on one or two targets (Figure 3), while MAs had three aims on average. According to our data, about $30 \%$ of MAs in 2001 had some development strategy. We can consider them as a little more related to the concept of integrated development, preferring realisation of long-term common targets in several domains. The main aims were similar as in the former analysed period, however, the SPUs reduced pressure on road construction and technical infrastructure, while MAs more often considered tourist development as one of the priorities for action.

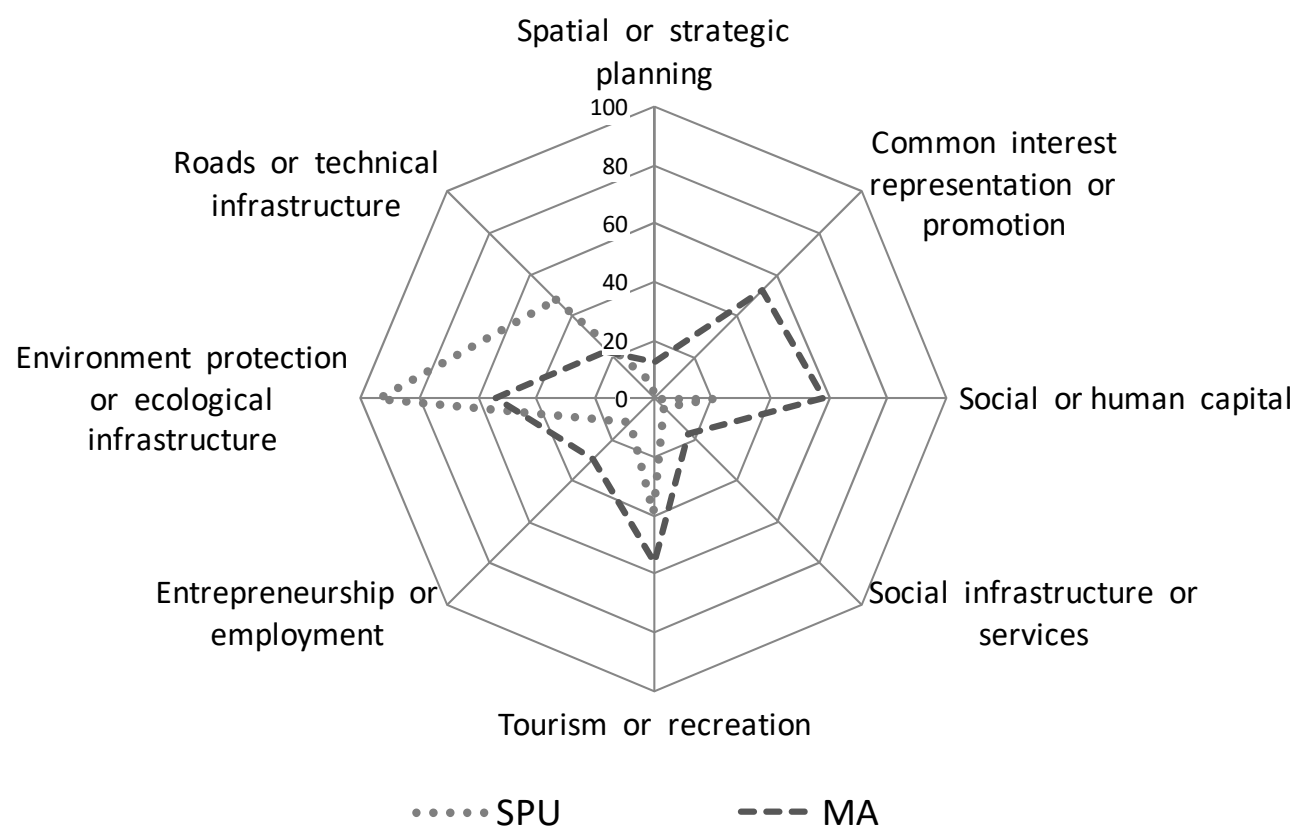

Figure 3. The percentage share of analysed organisations including a given subject in their priorities, by organisations created in years 1999-2004. SPU-Special Purpose Unions; MA-Municipal Associations. There were no formal LAGs in that period. The Authors' own research.

There were no formal LAGs in that period, however. A total of nearly 15-20 territorial partnership networks were established across the country, but only a few of these had legal status or formal structures such as a dedicated secretariat, so we cannot analyse their priorities from statutes or formal documents. Whilst the legal basis for municipal associations was straightforward, cross-sectoral partnership-based forms of cooperation faced a more difficult legal environment. The main problem was the absence of any legal framework of cooperation within which self-governments, voluntary organisations and 
business could participate on an equal basis, and there was often a lack of public government interest in co-operating with non-state actors in practice, especially if this meant transferring competences involving the management of public funds or having NGOs participating in decision making [91,92]. The Law on Associations allowed the creation of civil associations (in which only individual persons are full members) and, separately, municipal associations (in which only municipalities are members).

Poland's accession to the European Union on 1 May 2004 had major repercussions in terms of partnership creation. The EU programmes supported the creation of area-based, cross-sectoral rural development partnerships called LEADER Local Action Groups (LEADER is an acronym in French-Liaison entre actions de développement de l'économie rurale-meaning Links between actions for the development of the rural economy) and public municipal investment [93-95]. Initially, LAGs in Poland had to be a formal association, foundation or union of associations, on a compact territory inhabited by 10,000-100,000 persons, with a decision-making body in which the public sector could have no more than a 50 per cent share (LEADER + Pilot Programme [96]). In 2007, consequent to European Union demands and financial support, a new law enabled the creation of special associations with both individuals and different legal types of organisation as possible members in rural areas inhabited by 10,000-150,000 persons. This led to a total of 336 LAGs being registered across the country to participate in the EU Rural Development Programme 2007-2013 (initially 338 LAGs were created, but two did not eventually join the UE programme), which became the main form of co-operation with municipal engagement in rural areas; the most popular across the country. Most of them (324 LAGs) took the form of inter-municipal cooperation, with participation from 2 to 23 local governments in a cohesive functional region. They were obliged to create local development strategies. According to our study, LAGs in 2011 were focused on social or human capital, social infrastructure and services, entrepreneurship or employment and tourism or recreation (Figure 4). In comparison, SPUs established in this period focused continuously on environment protection and ecological infrastructure, while MAs focused on common interest representation and promotion. Comparing preferred goals of analysed forms of inter-municipal co-operation, we can see their specialisation in some issues.

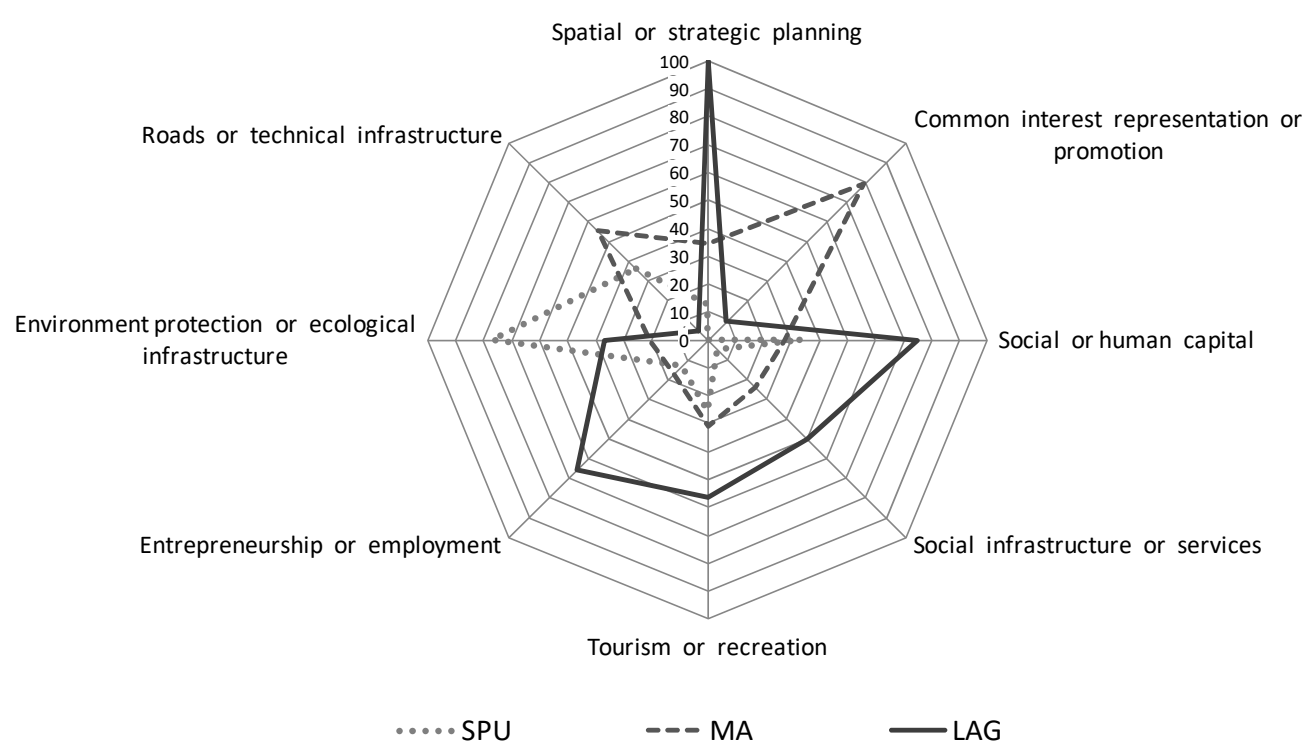

Figure 4. The percentage share of analysed organisations including a given subject in their priorities in units created in the years 2005-2013: SPU-Special Purpose Unions; MA-Municipal Associations; LAG-Local Actions Groups (data for 324 inter-municipal LAGs from 2011). The Authors' own research.

At the beginning of the EU 2014-2020 programming period, new rules and policies appeared. Collaboration in urban functional areas started to be a significant beneficiary of EU Integrated Territorial Investments (ITI) funding policy, pushing local governments to create unions or to sign agreements in 16 areas of voivodeships (regional) capitals (for detail see $[15,55]$ ). The main aim was to improve 
the quality of life in metropolitan functional regions consisting of urban and rural municipalities and impacted by urban sprawl [97-99]. The ITI Partnerships have various legal forms, most commonly municipal association and inter-municipal agreements, so they were not analysed separately in our research (a comparative study requires the separation of the forms studied). They focus on the development of public transport (including cycling paths), educational programmes for local inhabitants and thermo-modernisation of public buildings. They did not have strong cross-sectoral features, compared to LAGs.

In the case of LAGs, the central government new rules demanded cross-sectoral cooperation in a minimum of two municipalities (except urban LAGs) with 30,000-150,000 inhabitants (for more detailed rules see [53]). As a result, about 30 small LAGs had to be dissolved, and their member municipalities created new ones or joined larger neighbouring organisations. Less than 10 new SPUs and six MAs were created in the years 2014-2018.

In the middle of 2018, there were, in Poland, 322 LAGs (279 rural development, 35 piscatorial/fishing and eight urban in one municipality), 251 SPUs (243 inter-municipal and eight municipal-county) and nearly $92 \mathrm{MAs}$, so the cross-sectoral partnership remained the most common form of co-operation with municipal engagement.

Compared to the SPUs and MAs, the EU rules on inclusion of participants from business and the community sector in LAGs led to an increased emphasis on support for local business, social and human capital and social infrastructure (Figure 5, data from all organisations existing in 2018). However, the figure shows the extent of specialisation; SPUs deal mainly with technical and ecological infrastructure, whereas LAGs focus on social issues, local business, tourism and recreation. The LAGs are also more multi-purpose in character, because typically five to six types of aims were considered to be important for local integrated sustainable management, hence the integrated planning index (IPI) being higher for LAGs than for SPUs or MAs, even without a common "spatial or strategic planning" category, which is most commonly not stated in priorities but is obligatory for LAGs (Table 1).

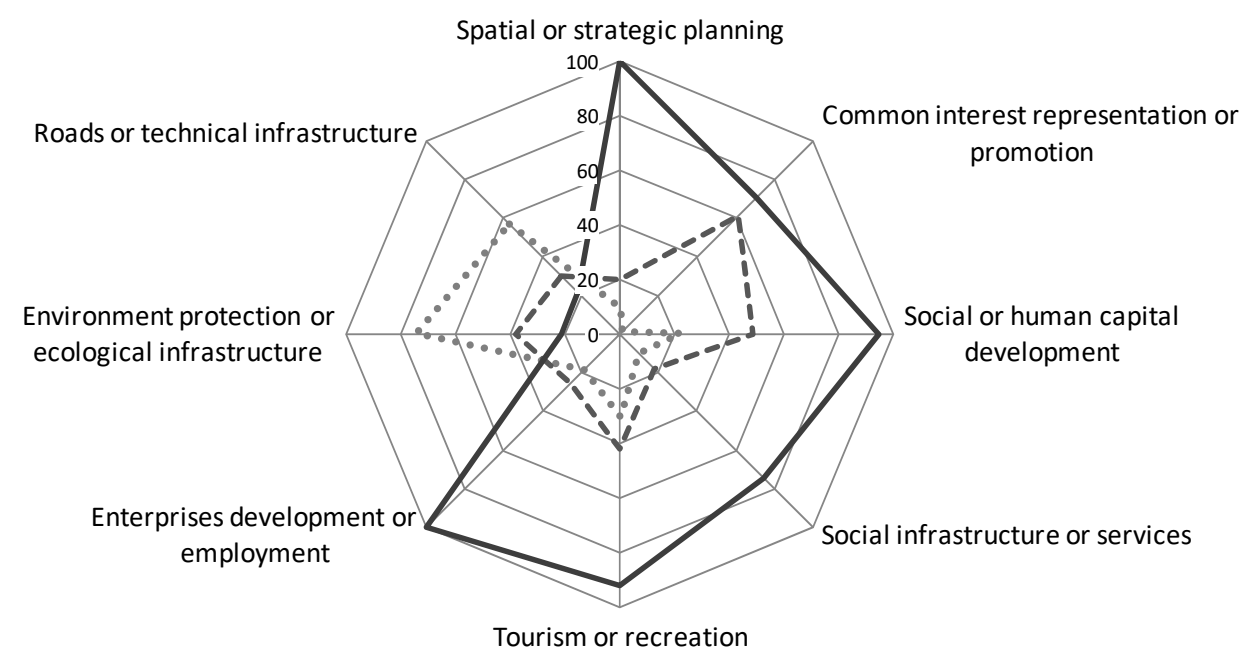

$$
\ldots \text {...SPU } \quad---M A \quad-L A G
$$

Figure 5. The percentage share of analysed organisations counting given subject in their priorities, by all analysed organisations existing in 2018: SPU—Special Purpose Unions; MA-Municipal Associations; LAG-Community-Led Local Development Local Actions Groups (data for 314 inter-municipal LAGs from 2018). The Authors' own research. 
Table 1. The integrated planning index (IPI) in three main forms of associations engaging local municipalities in Poland (2018). SPU-Special Purpose Unions; MA-Municipal Associations; LAG_Local Action Groups.

\begin{tabular}{cccc}
\hline SPU $^{1}$ & MA $^{2}$ & LAG $^{3}$ & Comments \\
\hline 27.7 & 35.4 & 71.9 & With "spatial or strategic planning" category \\
30.3 & 37.6 & 59.6 & Without "spatial or strategic planning" category \\
\hline
\end{tabular}

Source: Aims or main tasks listed in: $\left({ }^{1}\right)$ register of municipal SPUs and municipal-county SPUs $(\mathrm{N}=321) ;\left({ }^{2}\right)$ in statutes of MAs $(\mathrm{N}=92) ;\left({ }^{3}\right)$ in inter-municipal LAGs strategies $(\mathrm{N}=314)$. The Authors' own research (2018).

Table 2. The integrated planning index (IPI) in organisations established in given research periods in three main forms of cooperation engaging local municipalities in Poland. SPU—Special Purpose Unions; MA-Municipal associations; LAG_Local Action Groups.

\begin{tabular}{ccccc}
\hline Period & SPU & MA & LAG & Mean-All Forms \\
\hline $1990-1998$ & 28.7 & 37.5 & No LAGs & 33.1 \\
$1999-2004$ & 27.8 & 37.8 & No LAGs & 32.8 \\
$2005-2013$ & 25.3 & 36.2 & $49.7^{*}$ & 37.1 \\
$2014-2018$ & 17.5 & 32.1 & $71.9^{* *}$ & 40.5
\end{tabular}

*data for 324 inter-municipal LAGs existing in 2011; **data for 314 inter-municipal LAGs existing in 2018. Source: The Authors' own research (2019).

Analysis of IPI in the years 1990-2018 (Table 2) shows that the mean index increased from 33.1 to 40.5. The SPUs remain specialised in technical and ecological infrastructure (and it tends to increase, because IPI decreased from 28.7 to 17.5) and the MAs in common interest representation, tourist promotion and social and human capital development (with the most stable IPI; however, it decreased from 37.8 to 32.1). The LAGs take into consideration a much wider scope of works (IPI 71,9 in 2018), with special attention to business and social issues. Most likely, the LAGs took over part of the activities in the field of social issues and small business, and SPUs focused even more on large infrastructure investments, waste and transport management, which cannot be implemented by LAGs. The analysed data shows that the LAGs preferences are the closest to the concept of integrated and sustainable development, however, only simultaneous use of the analysed three forms of cooperation ensures that all analysed categories are covered by actions (visible on Figure 5).

\section{Discussion}

Our analyses have shown that mono-sectoral forms of inter-municipal cooperation in Poland differ from cross-sectoral, participative ones in terms of their local development priorities. The thesis was confirmed that participative territorial governance leads to a more balanced development, which takes account of various local social needs, without focusing only on infrastructure investments. This is partly the result of the requirements of the programs that control the creation of partnerships, but partly it can also be a bottom-up process, in line with Ostrom's theories [70]. However, since there are no similar comparative studies from other countries, it is difficult for us to assess whether this is a typical worldwide or a characteristic phenomenon mainly for Poland. Inter-Municipal Cooperation (IMC) analyses available in the literature suggest that former Eastern Bloc countries may have similar experiences, while countries with long democratic traditions and continually existing local government may slightly differ in the priorities of similar forms of territorial cooperation of local municipalities [18].

In this paper, the three main phases in the evolution of territorial cooperation in Poland have been identified, which can be categorised in terms of Bennett's stages of partnership cooperation development [61]:

- In the first phase after communism, the fragmentation of local self-governments created networks that were focused on fulfilling immediate physiological needs in underdeveloped areas (water and gas supply, waste management, etc.) and, accordingly, it was primarily sectoral, Special Purpose 
Unions that were created (Bennet's "early network"). The priorities were related to the main municipal functions. The extension of market relations made municipalities group together for economies of scale in management of resources, especially where natural environmental areas and economic links crossed local administrative boundaries. There were some features of bottom-up territorial development, however, the voluntary and business sectors were not included widely in the process of strategic planning and decision making. The government, even when decentralised, did not want to lose power. In that period, local government tended to regard Non-Governmental Organisations (NGOs) as rivals and a potential threat to their own influence and, at best, as not to be trusted collaborators [100]. This is perhaps not surprising as NGOs and local governments have often been on opposing sides in spatial planning conflicts [101,102]. Democratisation after 1990 gave local communities in Poland new freedoms and responsibilities, but modes of behaviour associated with the socialist system did not disappear and tended to co-exist alongside the new organisation of the state, as noted by Regulska [103] and Grosse [92]. Nonetheless, voluntary organisations did develop strong relationships with local authorities so that by the end of the 1990s local authorities had emerged as the most common supporter of NGOs [100]. However, support did not mean wide engagement in the management of municipal resources.

- When, through national administrative reform measures, new levels of self-governance were created in 1999-the districts (powiat) and regional councils (województwo)-local municipalities were mobilized to establish the regional and local associations to enhance their capacity to lobby regional and central government. The new bodies engaged more with business, tourism and social and human capital than had their predecessors. However, they remained mono-sectoral, municipal organisations with a relatively narrow list of aims and can be considered also as examples of Bennet's "early network".

- The last phase began after accession to the European Union, with minor changes at the beginning of EU programming periods. The creation of new forms of territorial cooperation with local municipality engagement were clearly stipulated by the EU policies and funds (Bennett's phase of "developing trust" between collaborators, with external agency support). The new forms were created mainly at the beginning of the support programmes, which provided a powerful incentive for their organisation. Such arrangements had scarcely been established prior to funding being available, so cannot be considered as a genuine national self-organisation process, but rather as policy transfer of the concept of place-based development. It can be considered also as "Europeanisation"; in this case, a conscious process of territorial development policy transfer to post-socialist countries led by European Union policymakers $[43,104]$. Funds and programmes originating in Western Europe played a significant role in mobilising local stakeholders to create partnerships and provide technical assistance, funding and investment possibilities. This process was common across all new EU member post-socialist states in Central and Eastern Europe $[78,105,106]$.

This evolution of cooperation can be considered as a "learning process" of the partnership formed management of local resources as stated by Bennett [61]. He compares different levels of effectiveness of partnerships (on the vertical axis) with the time it takes to develop effective working relationships (on the horizontal axis). After the initial stage of isolation, the following stage is development of expertise and experience (early networks for specific projects, in our case SPUs and MAs). Often in later stages, a broad range of agents interested in the development of the local economy may be linked together in effective commitment. At that stage, an external force such as a development agency or other institution (e.g., an external support programme; in our case, EU programmes) may play a central role, mobilising for cooperation, organising resources, providing technical consulting, etc. This can be referred to as the stage of trust development. A facilitator in the form of a neutral third party or a most active participant who serves as the initiator of the collaboration is critical in the formation and success of co-operative efforts [71]. 
We can deal with the most advanced stage of territorial partnership development (Bennet's "mature" stage) when it will be capable of functioning even without external financial support, based on local resources. However, it is difficult to say how many LAGs would survive after the end of support. In Pawłowska's survey, between 518 members from 26 LAGs in the Sub-Carpathian region in Poland, only $32 \%$ of respondents were sure that the LAGs can survive after closing EU financial support [107]. Such studies, assessing the extent to which Europeanisation processes are persistent, may be carried out after Britain's exit from the European Union. However, we must take into consideration that public-private partnerships for local development had a longer tradition in Anglo-Saxon countries, like the United Kingdom, than EU LEADER type programmes supporting rural development partnerships [26].

In many of the LAG strategies analysed, especially in 2011, the objectives were formulated as the names of the main budget lines of the support program. This suggests that the authors of the strategy first adapted to the program requirements to obtain funds more easily than to real local needs, which were then "tailored" to the requirements of the support program. According to some authors, this is a deliberate operation in place-based and neo-endogenous development concepts [7,48]. It assumes "steering" local initiatives with a "reward" in the form of financial resources, which can be largely associated with the theory of rational choice [108]. There are no restrictions or orders to act, as in authoritarian systems, but funds are obtained only for actions designated by central authorities in the support program procedures. Therefore, it cannot be considered as a classic grass-roots development, where local resources are used by residents completely according to their needs and priorities [29]. The mass establishment of LAGs in all EU countries partly confirms the effectiveness of such motivation of local elites for territorial cooperation [52].

In the current partnership model in Poland and other post-socialist countries, local authorities have consistently played an important role, although sometimes with features of tokenism [109-111]. However, in the management of common resources, there was a significant increase in the formal involvement of business and the voluntary sector. For local post-socialist communities, this stage can be considered as the learning process of new models of the integrated development and territorial governance [61,112]. However, also in developed countries, partnership relations are considered as a positive "adaptive co-management" based on self-learning social networks [113]. In this stage, the role of cultural and social issues increased in territorial strategies, with a significant movement towards the sustainable development idea [45].

The research findings show increased attention to social and local small business affairs in the new form of cross-sectoral collaboration, whereas the initial sectoral, inter-municipal cooperation had been focused mainly on technical infrastructure and public utilities and had been weakly integrated and was low on sustainability. These findings are similar to those of LAGs studies in EU post-socialist member states [12,114]. The mono-sectoral inter-municipal cooperation in this region are most often focused on the development and modernization of infrastructure necessary for directly carrying out their tasks, for instance in the Czech Republic, Slovenia and Romania [62,72,115]. However, according to Potkański [74], such an approach is short-sighted because, despite improving the quality of infrastructure and the momentary satisfaction of voters, it does not ensure long-term economic development, creating jobs or income sources for the local population. The LAGs helped to change the ordering of local priorities, paying greater attention to the role of social and human capital and small local business in local development. Partnership governance used in sustainable and integrated (place-based or neo-endogenous) development promotes the understanding that community development encompasses more than economic development. Wealth and technical infrastructure is an important element of quality of life, but it is only one element, and community development requires that quality of life issues are also addressed $[24,45,116]$. Bringing different social groups to a consensus is unlikely to be accomplished through a narrowly economic focus or infrastructure investments, as in SPUs. 
As technical infrastructural issues became less urgent, after a dozen years of investment, issues such as social and human capital building, socio-cultural infrastructure and small business have become a major focus for area-based cross-sectoral cooperation. The LAGs have pursued a wider range of aims per organisation, so they claim with justification to have a more comprehensive (integrated or sustainable) approach than have mono-functional SPUs and MAs. Such observations are in line with Ostrom's concepts [70]. She found that for any group to manage common resources (e.g., aquifers, judicial systems, pastures) for optimal sustainable production there should be established cooperation relations with a small set of design principles, addressing how to cope with free-riding, solving commitment problems, arranging for the supply of new institutions and monitoring individual compliance with that set of rules. Ostrom found that a group can successfully manage local resources when they have defined their territory clearly, the rules of use of collective goods are well matched to local needs and conditions and when most individuals affected by these rules can participate in modifying the rules, which are respected by external authorities. The group should have a common system of cooperation for monitoring members' behaviour (and the community members themselves should undertake this monitoring, using a graduated system of sanctions for users who break the rules) and the community members should have access to low-cost conflict resolution mechanisms. LAGs, although their features have been partly imposed by the requirements of the support program, partly confirm this approach. Despite the problems noted regarding power relations and participation of non-public entities, they clearly enable meeting a greater range of local communities' needs and are characterised by more balanced and integrated local development planning than in the case of mono-sectoral cooperation of public authorities. However, it is probably more typical for post-socialist new EU member states, because in the established democracies, IMC deals with social and cultural issues to a greater extent [117-119]. For example, in Switzerland, municipal cooperation focused in the 1990s on school issues and health care, followed by sewage system and waste disposal [20]. However, the differences could be results of formal competences and public administration organisation, not only of local government.

These analyses also indicate that in Poland changes in methods of co-management of local resources have not been of a gradual and evolutionary character, as in many countries with long local democratic traditions [120,121], but rather have a "stepping" character. Each phase of territorial co-operation in Poland involving municipalities was initiated by radical legislative changes (creation of self-government in 1990, administrative reform implemented in 1999, and joining the European Union in 2004), which created the impulse towards other forms of co-operation development. This shows a degree of inertia in administration systems, such that only a strong external impulse can initiate significant changes. Hence, the entry of post-socialist countries into the European Union was for them a very important factor that accelerated their transformation. Despite the inclination of some populist governments of these countries to limit democratic principles [122], or to take control on cross-sectoral partnerships [111], it is possible that some of the positive changes will take root in time sufficiently to survive possible future reductions in financial support for participatory forms of inter-municipal cooperation [123].

\section{Conclusions}

In this paper, we analysed the evolution of development priorities in three main forms of domestic municipal cooperation in Poland: mono-sectoral Special Purpose Unions and Municipal Association, and in cross-sectoral Local Action Groups, which are also common in other European countries. The main findings can be summarised in six groups:

- First, the process of area-based partnership creation in post-socialist EU member states was a conscious process of place-based or neo-endogenous development policy transfer, considered as an element of the process of Europeanisation. The rapid development of territorial partnerships is self-evidently the result of special EU financial support policy (supporting the theory of rational 
choice [108]) and it is therefore difficult to predict the long-term durability of the sponsored organisations if this support is reduced or terminated;

- Second, the evolution of inter-municipal cooperation in transitional post-socialist Poland has more of a step character than the longer-term evolution associated with countries with longer experience of democratic local self-government. The main stages were initiated by radical legislative changes (creation of self-government in 1990, administrative reform implemented in 1999, and joining the European Union in 2004 with its consequences in terms of changed policies in their programming periods);

- Third, the territorial cross-sectoral partnerships are most frequently forms of inter-municipal cooperation that have more sustainable and integrated features of development planning than mono-sectoral forms led solely by government, and are taking more account of social and small business issues;

- Fourth, the three forms of cooperation present some features of specialisation-SPUs focus most commonly on "hard" infrastructure and waste management; MAs on "soft" actions like common municipal representation and promotion and public administration development; LAGs on social and human capital building, small business development, tourism and recreation;

- Finally, the new forms of cooperation do not replace the old ones, but can and do exist simultaneously. However, the greater potential of area-based cross-sectoral partnerships (such as LAGs) has become increasingly evident.

According to the literature, cross-sectoral territorial partnerships can be effective in the implementation of integrated strategies for sustainable management of local resources in developing countries [124-126]. Even if scholars observe problems of power-relations in bottom-up governance [111,127], this learning process of cross-sectoral collaboration in functional areas could be important for more participative and sustainable planning in countries with weak democratic traditions. In addition, we recommend that we should not limit the overviews of inter-municipal cooperation to the mono-sectoral cooperation of local authorities, but also take into account inter-municipal, cross-sectoral partnerships, in which local authorities make decisions together with representatives of the social and economic sector.

Author Contributions: Conceptualization, M.F.; methodology, M.F.; software, M.F.; validation, M.F.; investigation, M.F.; formal analysis, M.F.; resources, M.F.; data curation, M.F.; writing-original draft, M.F. and A.C.; writing-review and editing, M.F. and A.C.; visualization, M.F.; supervision, M.F.; project administration, M.F.; funding acquisition, M.F.; overall share in works: M.F, 70\%; A.C., 30\%.

Funding: We are grateful to the Ministry of Science and Higher Education (MNiSW, Poland) for supporting open access publishing in the framework of the Statutory Funds of Department of Spatial Economy at the Wrocław University of Environmental and Life Sciences.

Conflicts of Interest: The authors declare no conflict of interest. The funders had no role in the design of the study; in the collection, analyses, or interpretation of data; in the writing of the manuscript, or in the decision to publish the results.

\section{References}

1. Adaptative Co-menagement: Collaboration, Learning and Multi-Level Governance; Armitage, D.F.; Berkes, F.; Doubleday, N. (Eds.) University of British Columbia: Vancouver, Canada, 2007.

2. Simard, J.-F.; Chiasson, G. Introduction: Territorial governance: A new take on development. Can. J. Reg. Sci. 2008, 31, 471-485.

3. Stead, D. The Rise of Territorial Governance in European Policy. Eur. Plan. Stud. 2014, 22, $1368-1383$. [CrossRef]

4. Ray, C. Neo-endogenous rural development in the EU. In Handbook of Rural Studies; Cloke, P., Marsden, T., Mooney, P., Eds.; Sage: London, UK, 2006; pp. 278-291.

5. Canete, A.J.; Navarro, F.; Cejudo, E. Territorially unequal rural development: The cases of the LEADER Initiative and the PRODER Programme in Andalusia (Spain). Eur. Plan. Stud. 2018, 26, 726-744. [CrossRef] 
6. Scott, M. Delivering Integrated Rural Development: Insights from Northern Ireland. Eur. Plan. Stud. 2002, 10, 1013-1025. [CrossRef]

7. Zaucha, J.; Świątek, D. Place-Based Territorially Sensitive and Integrated Development; Ministry of Regional Development: Warsaw, Poland, 2013.

8. George, C.; Reed, M.G. Operationalising just sustainability: Towards a model for place-based governance. Local Environ. 2015, 22, 1105-1123. [CrossRef]

9. Bosworth, G.; Annibal, I.; Carroll, T.; Price, L.; Sellick, J.; Shepherd, J. Empowering Local Action through Neo-Endogenous Development; The Case of LEADER in England. Sociol. Rural. 2016, 56, 427-449. [CrossRef]

10. Markowski, T. Territorial dimensions of integrated development policy-Expectations and challenges concerning planning and institutional systems. Stud. Reg. 2013, 35, 51-64.

11. Therese, B.; Sandström, C. Public-private partnerships in a Swedish rural context-A policy tool for the authorities to achieve sustainable rural development? J. Rural Stud. 2016, 49, 58-68.

12. Kis, K.; Gal, J.; Veha, A. Effectiveness, efficiency and sustainability in local rural development partnerships. APSTRACT Appl. Stud. Agribus. Commer. 2012, 6, 31-38. [CrossRef]

13. Gorlach, K.; Adamski, T.; Klekotko, M. Poland: Designing Nature and Resource Management Strategies. In Rural Sustainable Development in the Knowledge Society; Bruckmeier, K., Tovey, H., Eds.; Ashgate: Surrey, UK, 2009; pp. 187-202.

14. Macken-Walsh, Á.; Curtin, C. Governance and Rural Development: The Case of the Rural Partnership Programme (RPP) in Post-Socialist Lithuania. Sociol. Rural. 2013, 53, 246-264. [CrossRef]

15. Kaczmarek, T.; Kociuba, D. Models of governance in the urban functional areas: Policy lessons from the implementation of integrated territorial investments (ITIs) in Poland. Quaest. Geogr. 2017, 36, 47-64. [CrossRef]

16. Doitchinova, J.; Stoyanova, Z. Activation of local communities for development of rural areas. Econ. Agric. 2014, 61, 661-675. [CrossRef]

17. Inter-Municipal Cooperation in Europe; Hulst, R.; van Montfort, A. (Eds.) Springer: Dordrecht, The Netherlands, 2007.

18. Inter-Municipal Cooperation in Europe: Institutions and Governance; Teles, F.; Swianiewicz, P. (Eds.) Palgrave Macmilian: Cham, Switzerland, 2018.

19. Dołzbłasz, S.; Raczyk, A. Different Borders-Different Cooperation? Transborder Cooperation in Poland. Geogr. Rev. 2015, 105, 360-376. [CrossRef]

20. Steiner, R. The causes, spread and effects of intermunicipal cooperation and municipal mergers in Switzerland. Public Manag. Rev. 2003, 5, 551-571. [CrossRef]

21. Hulst, R.; van Montfort, A. Institutional features of inter-municipal cooperation: Cooperative arrangements and their national contexts. Public Policy Adm. 2012, 27, 121-144. [CrossRef]

22. Namyślak, B. Cooperation and Forming Networks of Creative Cities: Polish Experiences. Eur. Plan. Stud. 2014, 22, 2411-2427. [CrossRef]

23. OECD. The Future of Rural Policy. From Sectoral to Place-Based Policies in Rural Areas; Organisation for Economic Co-Operation and Development: Paris, France, 2003.

24. Shortall, S.; Shucksmith, M. Integrated rural development: Issues arising from the Scottish experience. Eur. Plan. Stud. 1998, 6, 73-89. [CrossRef]

25. Swianiewicz, P.; Gendźwiłł, A.; Krukowska, J.; Lackowska, M.; Picej, A. Wspótpraca międzygminna w Polsce; Wydawnictwo Naukowe Scholar: Warszawa, Poland, 2016.

26. Local Partnerships for Rural Development. The European Experience; Moseley, M.J. (Ed.) CABI Publishing: Wallingford Oxon, UK, 2003.

27. Lowe, P.; Murdoch, J.; Ward, N. Beyond endogenous and exogenous models: Networks in rural development. In Beyond Modernisation: The Impact of Endogenous Rural Development; van der Ploeg, J.D., van Dijk, G., Eds.; Van Gorcum: Assen, The Netherlands, 1995; pp. 87-105.

28. Slee, B. Theoretical aspects of the study of endogenous development. In Born From within: Practice and Perspectives of Endogenous Rural Development; van der Ploeg, J.D., Long, A., Eds.; Van Gorcum: Assen, The Netherlands, 1994; pp. 184-194.

29. Willis, K. Theories and Practices of Development; Routledge: Oxon, NY, USA, 2005.

30. Bański, J. Dilemmas for Regional Development in the Concepts Seeking to Develop Poland's Spatial Structure. Reg. Stud. 2010, 44, 535-549. [CrossRef] 
31. Regulski, J. Local Government Reform in Poland: An Insider's Story; Open Society and Local Government and Public Service Reform Initiative: Budapest, Hungary, 2003; p. 263.

32. Coulson, A.; Campbell, A. Local government in central and Eastern Europe: Introduction. Local Gov. Stud. 2006, 32, 539-541. [CrossRef]

33. Bowler, I. Endogenous agricultural development in Western Europe. Tijdschrift Economische Sociale Geografie 1999, 90, 260-271. [CrossRef]

34. Dutkowski, M.; Parysek, J.J. Going green: Sustainable development as a model of socio-economic development in European post-communist countries. Eur. Plan. Stud. 1994, 2, 419-434.

35. Świąer, M. The implementation of the concept of environmental carrying capacity into spatial management of cities: A review. Manag. Environ. Qual. 2018, 29, 1059-1074. [CrossRef]

36. Barke, M.; Newton, M. The EU LEADER Initiative and Endogenous Rural Development: The Application of the Programme in Two Rural Areas of Andalusia, Southern Spain. J. Rural Stud. 1997, 13, 319-341. [CrossRef]

37. Rhodes, R.A.W. The New Governance: Governing without Government. Polit. Stud. 1996, 44, $652-667$. [CrossRef]

38. Peters, B.G.; Pierre, J. Governance Without Government? Rethinking Public Administration. J. Public Adm. Res. Theory 1998, 8, 223-243. [CrossRef]

39. Abers, R. From clientelism to cooperation: Local government, participatory policy, and civic organizing in Porto Alegre, Brazil. Polit. Soc. 1998, 26, 511-538. [CrossRef]

40. Ackerman, J. Co-Governance for Accountability: Beyond "Exit" and "Voice". World Dev. 2004, 32, 447-463. [CrossRef]

41. Thuesen, A.A.; Nielsen, N.C. A territorial perspective on EU's LEADER approach in Denmark: The added value of community-led local development of rural and coastal areas in a multi-level governance settings. Eur. Countrys. 2014, 6, 307-326. [CrossRef]

42. Chevalier, P.; Mačiulyté, J.; Razafimahefa, L.; Dedeire, M. The LEADER programme as a model of institutional transfer: Learning from its local implementation in France and Lithuania. Eur. Countrys. 2017, 2, 317-341. [CrossRef]

43. Dabrowski, M. Shallow or deep Europeanisation? The uneven impact of EU cohesion policy on the regional and local authorities in Poland. Environ. Plan. C Gov. Policy 2012, 30, 730-745. [CrossRef]

44. Kanak, S.; Iiguni, Y. The role of social capital in endogenous development. J. Rural Probl. 2005, 41, 180-184. [CrossRef]

45. Dargan, L.; Shucksmith, M. LEADER and Innovation. Soc. Rural. 2008, 48, 274-291. [CrossRef]

46. Petrick, M. Reversing the rural race to the bottom: An evolutionary model of neo-endogenous rural development. Eu. Rev. Agric. Econ. 2013, 40, 707-735. [CrossRef]

47. Wellbrock, W.; Roep, D.; Mahon, M.; Kairyte, E.; Nienaber, B.; Dolores, M.; García, D.; Kriszan, M.; Farrell, M. Arranging public support to unfold collaborative modes of governance in rural areas. J. Rural Stud. 2013, 32, 420-429. [CrossRef]

48. Böcher, M. Regional Governance and Rural Development in Germany: The Implementation of LEADER+. Soc. Rural. 2008, 48, 372-388. [CrossRef]

49. Barca, F. An Agenda for a Reformed Cohesion Policy. A Place-Based Approach to Meeting European Union Challenges and Expectations; Economics and Econometrics Research Institute: Brussels, Belgium, 2009.

50. Mendez, C. The post-2013 reform of EU cohesion policy and the place-based narrative. J. Eur. Public Policy 2013, 20, 639-659. [CrossRef]

51. Churski, P.; Kociuba, D.; Ochojski, A.; Polko, A. Towards Policy-Place-Based Policy and Smart Specialisation. In Measuring Regional Specialisation; Kopczewska, K., Churski, P., Ochojski, A., Polko, A., Eds.; Springer: Berlin, Germany, 2017; pp. 267-380.

52. Konečný, O. The Leader Approach Across the European Union: One Method of Rural Development, Many Forms of Implementation. Eur. Countrys. 2019, 11, 1-16. [CrossRef]

53. Aldorfai, G.; Czabadai, L.; Topa, Z. An innovative methodology for supporting the CLLD. Pol. J. Manag. Stud. 2016, 13, 7-17. [CrossRef]

54. Servillo, L.; De Bruijn, M. From LEADER to CLLD: The Adoption of the New Fund Opportunities and of Their Local Development Options. Eur. Struct. Invest. Funds J. 2018, 6, 223-233.

55. Kociuba, D. Implementation of Integrated Territorial Investments in Poland-Rationale, Results, and Recommendations. Quaest. Geogr. 2018, 37, 81-98. [CrossRef] 
56. Zajda, K.; Kołomycew, A.; Sykała, Ł.; Janas, K. Leader and Community-Led Development Approach. Polish Experiences; Wydawnictwo Uniwersytetu Łódzkiego: Łódź, Poland, 2017.

57. Faludi, A. Place is a no-man's land. Geographia Polonica 2015, 88, 5-20. [CrossRef]

58. Masot, A.N.; Alonso, G.C.; Moreno, L.M.C. Principal Component Analysis of the LEADER Approach (2007-2013) in South Western Europe (Extremadura and Alentejo). Sustainability 2019, 11, 4034. [CrossRef]

59. Hełdak, M.; Raszka, B. Evaluation of the Local Spatial Policy in Poland with Regard to Sustainable Development. Pol. J. Environ. Stud. 2013, 22, 395-402.

60. Stacherzak, A.; Hełdak, M.; Raszka, B. Planning Documents and Sustainable Development of a Commune in Poland. Wit Trans. Ecol. Environ. 2012, 162, 23-34.

61. Bennett, R.J. Local Government in Post-Socialist Cities; Open Society Institute, Local Government and Public Service Reform Initiative: Budapest, Hungary, 1997.

62. Săgeată, R. Inter-communal cooperation and regional development: The case of Romania. Quaest. Geogr. 2012, 31, 95-106. [CrossRef]

63. Kozlova, O.A.; Makarova, M.N. Inter-Municipal Cooperation as an Institution of Strategic Development of Territories. Econ. Soc. Chang. Facts Trends Forecast 2018, 11, 132-144.

64. Nunn, S.; Rosentraub, M.S. Dimension of interjurisdictional cooperation. J. Am. Plan. Assoc. 1997, 63, 205-219. [CrossRef]

65. Ruszkai, C.; Kovács, T. The Community Initiative LEADER I and the implementation and results of the Hungarian Pilot LEADER programme in rural development. Bull. Geogr. Soc. Econ. Ser. 2012, 19, 87-97. [CrossRef]

66. Bel, G.; Fageda, X.; Mur, M. Why Do Municipalities Cooperate to Provide Local Public Services? An Empirical Analysis. Local Gov. Stud. 2013, 39, 435-454. [CrossRef]

67. Szewrański, S.; Kazak, J.; Szkaradkiewicz, M.; Sasik, J. Flood risk factors in suburban area in the context of climate change adaptation policies-Case study of Wroclaw, Poland. J. Ecol. Eng. 2015, 16, 13-18. [CrossRef]

68. Szewrański, S.; Świąder, M.; Kazak, J.; Tokarczyk-Dorociak, K.; Van Hoof, J. Socio-Environmental Vulnerability Mapping for Environmental and Flood Resilience Assessment: The Case of Ageing and Poverty in the City of Wroclaw, Poland. Integr. Environ. Assesment Manag. 2018, 14, 592-597. [CrossRef]

69. Bennett, R.J. Administrative Systems and Economic Spaces. Reg. Stud. 1997, 31, 323-336. [CrossRef]

70. Ostrom, E. Governing the Commons. The Evolutions of Institutions for Collective Action; Cambridge University Press: Cambridge, UK, 1990.

71. Lackey, S.B.; Freshwater, D.; Rupasingha, A. Factors Influencing Local Government Cooperation in Rural Areas: Evidence from the Tennessee Valley. Econ. Dev. Q. 2002, 16, 138-154. [CrossRef]

72. Rus, P.; Nared, J.; Bojnec, Š. Forms, areas, and spatial characteristics of intermunicipal cooperation in the Ljubljana Urban Region. Acta Geogr. Slov. 2018, 58, 47-61. [CrossRef]

73. Swianiewicz, P. If territorial fragmentation is a problem, is amalgamation a solution? An East European perspective. Local Gov. Stud. 2010, 36, 183-203. [CrossRef]

74. Wspótpraca jednostek samorzadu terytorialnego narzędziem wsparcia polskiej polityki rozwoju; Potkański, T. (Ed.) Związek Miast Polskich: Poznań, Poland, 2016.

75. Hutchinson, J. The Practice of Partnership in Local Economic Development. Local Gov. Stud. 1994, 20, 335-344. [CrossRef]

76. Bristow, G. Structure, Strategy and Space: Issues of Progressing Integrated Rural Development in Wales. Eur. Urban Reg. Stud. 2000, 7, 19-33. [CrossRef]

77. Zajda, K. Problems of functioning of Polish local action groups from the perspective of the social capital concept. Eastern Eur. Countrys. 2014, 20, 73-97. [CrossRef]

78. Bumbalová, M.; Takáč, I.; Tvrdoňová, J.; Valach, M. Are stakeholders in Slovakia ready for community-led local development? Case study findings. Eur. Countrys. 2016, 2, 160-174. [CrossRef]

79. Furmankiewicz, M. Współrządzenie czy ukryta dominacja sektora publicznego? Koncepcja governance w praktyce Lokalnych Grup Działania LEADER. Studia Regionalne Lokalne 2013, 1, 71-89.

80. Esparcia, J.; Escribano, J.; Serrano, J.J. From development to power relations and territorial governance: Increasing the leadership role of LEADER Local Action Groups in Spain. J. Rural Stud. 2015, 42, $29-42$. [CrossRef]

81. Goodwin, M. The Governance of Rural Areas: Some Emerging Research Issues and Agendas. J. Rural Stud. 1998, 14, 5-12. [CrossRef] 
82. The LEADER Method. Transferring Experience of the Visegrad Group Countries to Georgia; SykałaŁDej, M.; Wolski, O. (Eds.) Institute of Urban Development: Kraków, Poland, 2015.

83. Kołsut, B. Zinstytucjonalizowane Sieci Wspótdziałania Międzygminnego; Bogucki Wydawnictwo Naukowe: Poznań, Poland, 2015.

84. Prasal, D.B. Content Analysis. A method of Social Science Research. In Research Methods for Social Work; Lal Das, D.K., Bhaskaran, V., Eds.; Rawat: New Delhi, India, 2008; pp. 173-193.

85. Babbie, E. The Basics of Social Research, 5th ed.; Cengage Learning: Wadsworth, UH, USA, 2011.

86. Lošták, M.; Hudečková, H. Preliminary impacts of the LEADER+ approach in the Czech Republic. Agric. Econ. Zemědělská Ekonomika 2010, 56, 249-265. [CrossRef]

87. Svobodová, H. Do the Czech Local Action Groups Respect the LEADER Method? Acta Univ. Agric. Silvicult. Mendelianae Brunensis 2015, 63, 1769-1777. [CrossRef]

88. Chen, C.; Li, D.; Man, C. Toward Sustainable Development? A Bibliometric Analysis of PPP-Related Policies in China between 1980 and 2017. Sustainability 2019, 11, 142. [CrossRef]

89. Furmankiewicz, M.; Thompson, N.; Zielińska, M. Area-based partnerships in rural Poland: The post-accession experience. J. Rural Stud. 2010, 26, 52-62. [CrossRef]

90. Meurs, M.; Kochut, R. Local government performance in rural Poland: The roles of local government characteristics and inherited conditions. Landbauforschung Appl. Agric. Forest. Res. 2014, 64, 163-178.

91. Dabrowski, M. EU cohesion policy, horizontal partnership and the patterns of sub-national governance: Insights from Central and Eastern Europe. Eur. Urban Reg. Stud. 2014, 21, 364-383. [CrossRef]

92. Grosse, T.G. Social dialogue during Enlargement: The case of Poland and Estonia. Acta Politica 2010, 45, 112-135. [CrossRef]

93. Chmieliński, P. On Community Involevement in Rural Development-A Case of Leader Programme in Poland. Econ. Soc. 2011, 4, 120-128. [CrossRef]

94. Błąd, M.; Kamiński, R. Social capital enhancement in the Polish countryside: Experiences from the implementation of LEADER-type programmes. In Development in the Enlarged European Union; Zawalińska, K., Ed.; Institute of Rural and Agricultural Development, Polish Academy of Sciences: Warszawa, Poland, 2005; pp. 235-247.

95. Kachniarz, M.; Szewranski, S.; Kazak, J. The Use of European Funds in Polish and Czech Municipalities. A Study of the Lower Silesia Voivodship and Hradec Kralove Region. IOP Conf. Ser. Mater. Sci. Eng. 2019, 471, 1-8. [CrossRef]

96. Furmankiewicz, M.; Knieć, W.; Atterton, J. Rural governance in the new EU member states: The experience of the Polish LEADER+ Pilot Programme (2004-2008). In Governance in Transition; Buček, J., Ryder, A., Eds.; Springer Geography: Dordrecht, The Netherlands, 2015; pp. 133-153.

97. Kaczmarek, T. Collaboration between local governments in metropolitan areas-Determinants, current situation and perspectives for the future. In Towards Urban-Rural Partnerships in Poland: Preconditions and Potential; Dej, M., Janas, K., Wolski, O., Eds.; Instytut Rozwoju Miast: Kraków, Poland, 2014; pp. 41-55.

98. Przybyła, K.; Kulczyk-Dynowska, A.; Kachniarz, M. Quality of Life in the Regional Capitals of Poland. J. Econ. Issues 2014, 48, 181-195. [CrossRef]

99. Tokarczyk-Dorociak, K.; Kazak, J.; Szewrański, S. The Impact of a Large City on Land Use in Suburban Area-The Case of Wroclaw (Poland). J. Ecol. Eng. 2018, 19, 89-98. [CrossRef]

100. Grochowski, M.; Regulska, J. New Partnership and Collaboration: Local Government and Its Supporting Institutions-The Case of Poland. In Towards a New Concept of Local Self-Government? Recent Local Government Legislation in Comparative Perspective; Amnå, E., Montin, S., Eds.; Fagbokforlaget: Bergen, Norway, 2000; pp. 73-100.

101. Kurek, W.; Faracik, R.; Mika, M. Ecological conflicts in Poland. GeoJournal 2001, 54, 507-516. [CrossRef]

102. Furmankiewicz, M.; Potocki, J.; Kazak, J. Land-Use Conflicts in the Sudetes, Poland. IOP Conf. Ser. Mater. Sci. Eng. 2019, 471, 1-10. [CrossRef]

103. Regulska, J. Governance or Self-governance in Poland? Benefits and Threats 20 Years Later. Int. J. Polit. Cult. Soc. 2009, 22, 537-556. [CrossRef]

104. Kołsut, B. Inter-Municipal Cooperation in Waste Management: The Case of Poland. Quaest. Geogr. 2016, 35, 91-104. [CrossRef]

105. Katona-Kovács, J.; High, C.; Nemes, G. Importance of Animation Actions in the Operation of Hungarian Local Action Groups. Eur. Countrys. 2011, 3, 227-240. [CrossRef] 
106. Doitchinova, J.; Miteva, A.; Stoyanova, Z. The process of creating local action groups in Bulgaria-Problems and prospects. Sci. Ann. Alexandru Ioan Cuza Univ. Iaşi Econ. Sci. 2012, 59, 183-208. [CrossRef]

107. Pawłowska, A. Territorial Partnerships in Rural Regions-Neo-Institutional Perspective. Pol. Sociol. Rev. 2017, 1, 95-108.

108. Furmankiewicz, M. LEADER+ territorial governance in Poland: Successes and failures as a rational choice effect. Tijdschrift Economische Sociale Geografie 2012, 103, 261-275. [CrossRef]

109. Marquardt, D.; Möllers, J.; Buchenrieder, G. Social Networks and Rural Development: LEADER in Romania. Soc. Rural. 2012, 52, 398-431. [CrossRef]

110. Zajda, K. New Forms of Social Capital of Rural Areas. A Case Study of Selected Polish Local Action Groups; LAP Lambert Academic Publishing: Saarbrücken, Germany, 2014.

111. Furmankiewicz, M.; Macken-Walsh, Á. Government within governance? Polish rural development partnerships through the lens of functional representation. J. Rural Stud. 2016, 46, 12-22. [CrossRef]

112. Adamski, T.; Gorlach, K. Neo-Endogenous Development and the Revalidation of Local Knowledge. Pol. Sociol. Rev. 2007, 160, 481-497.

113. Pappalardo, G.; Sisto, R.; Pecorino, B. Is the Partnership Governance Able to Promote Endogenous Rural Development? A Preliminary Assessment Under the Adaptive Co-Management Approach. Eur. Countrys. 2018, 10, 543-565. [CrossRef]

114. Naydenov, N.; Bogdanova, Z. Strategic \& organizational problems of "LEADER" approach application as a tool for sustainable rural development in Bulgaria. In Values and Challenges in Designing the European Rural Structures—Research Network Experience; Voicilas, D.M., Tudor, M., Eds.; European Rural Development Network: Warsaw, Poland, 2007; pp. 53-61.

115. Lysek, J.; Šaradín, P. Mapping the Success: Inter-municipal Cooperation in Two Czech Micro-regions. In Inter-Municipal Cooperation in Europe: Institutions and Governance; Teles, F., Swianiewicz, P., Eds.; Palgrave Macmilian: Cham, Switzerland, 2018; pp. 315-326.

116. Freshwater, D.; Thurston, L.; Ehrensaft, P. Characteristics of successful community development partnership strategies. In The Structure, Theory and Practice of Partnership in Rural Development; Rounds, R.C., Ed.; Agriculure and Rural Restructuring Group, Rural Development Institute: Brandon, MB, Canada, 1993; pp. 3-23.

117. Swianiewicz, P.; Teles, F. Inter-municipal Cooperation Diversity, Evolution and Future Research Agenda. In Inter-Municipal Cooperation in Europe: Institutions and Governance; Teles, F., Swianiewicz, P., Eds.; Palgrave Macmilian: Cham, Switzerland, 2018; pp. 335-350.

118. Klok, P.-J.; Boogers, M.; Denters, B.; Sanders, I.T. Inter-municipal Cooperation in the Netherlands. In Inter-Municipal Cooperation in Europe: Institutions and Governance; Teles, F., Swianiewicz, P., Eds.; Palgrave Macmilian: Cham, Switzerland, 2018; pp. 157-171.

119. Eythórsson, G.T. Bigger and Stronger Together: How Icelandic Municipalities Solve their Lack of Capacity and Scale Economy. In Inter-Municipal Cooperation in Europe: Institutions and Governance; Teles, F., Swianiewicz, P., Eds.; Palgrave Macmilian: Cham, Switzerland, 2018; pp. 209-224.

120. Hertzog, R. Inter-municipal Cooperation in France: A Continuous Reform, New Trends. In Inter-Municipal Cooperation in Europe: Institutions and Governance; Teles, F., Swianiewicz, P., Eds.; Palgrave Macmilian: Cham, Switzerland, 2018; pp. 133-155.

121. Steiner, R.; Kaiser, C. Inter-municipal Cooperation in Switzerland. In Inter-Municipal Cooperation in Europe: Institutions and Governance; Teles, F., Swianiewicz, P., Eds.; Palgrave Macmilian: Cham, Switzerland, 2018; pp. 173-187.

122. Levitsky, S.; Ziblatt, D. How Democracies Die; Penguin Books Ltd.: London, UK, 2018.

123. Kovách, I.; Kučerová, E. The Project Class in Central Europe: The Czech and Hungarian Cases. Soc. Rural. 2006, 46, 3-21. [CrossRef]

124. Petrick, M.; Gramzow, A. Harnessing Communities, Markets and the State for Public Goods Provision: Evidence from Post-Socialist Rural Poland. World Dev. 2012, 40, 2342-2354. [CrossRef]

125. Vrabková, I.; Pavel, Š. The Technical Efficiency of Local Action Groups: A Czech Republic Case Study. Acta Univ. Agric. Silvicult. Mendelianae Brunensis 2017, 65, 1065-1074. [CrossRef] 
126. Chmieliński, P.; Faccilongo, N.; Fiore, M.; La Sala, P. Design and implementation of the Local Development Strategy: A case study of Polish and Italian Local Action Groups in 2007-2013. Stud. Agric. Econ. 2018, 120, 25-31. [CrossRef]

127. Antonio Navarro, F.; Woods, M.; Cejudo, E. The LEADER Initiative has been a Victim of Its Own Success. The Decline of the Bottom-Up Approach in Rural Development Programmes. The Cases of Wales and Andalusia. Sociol. Rural. 2016, 56, 270-288. [CrossRef]

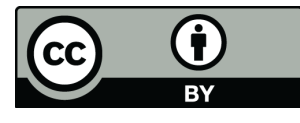

(C) 2019 by the authors. Licensee MDPI, Basel, Switzerland. This article is an open access article distributed under the terms and conditions of the Creative Commons Attribution (CC BY) license (http://creativecommons.org/licenses/by/4.0/). 